\title{
Near-bankruptcy of the Taiwan High Speed Rail Corporation:
}

\section{What Went Wrong?}

\author{
Peter YU Kien-hong \\ School of Business and Design, Swinburne University of Technology \\ Jalan Simpang Tiga 93350 Kuching, Sarawak, Malaysia \\ E-mail: pyu@swinburne.edu.my \\ Jokull Johannesson (Corresponding author) \\ Northampton Business School, University of Northampton \\ Park Campus Boughton Green Road, Northampton NN2 7AL, UK \\ E-mail: jokull.johannesson@northampton.ac.uk
}

\begin{abstract}
After a few delays, the Taiwan High Speed Rail (THSR), which is the largest current Build-Operate-Transfer (BOT) Railway Project in the world, with eight stations on the line connecting the metropolises of Taipei and Kaohsiung, began its passenger service in January 2007. However, by February 2009, it became very clear that the Taiwan area government must take over the THSR Corporation (THSRC) in one way or another, because the latter had already mired in enormous debts, loosing roughly two thirds of its capitalization. The THSR was only able to break even once in April 2008. This paper spells out the major reasons behind the project's near-bankruptcy. Some questions will be posed: Who are involved? Who should be responsible for the failure? Should business entrepreneurs venture into High Speed Rail (HSR) projects in the future?
\end{abstract}

Keywords: Taiwan, BOT, Turnkey, Taiwan High Speed Rail Corporation, Business failure

\section{Introduction}

Build-Operate-Transfer (BOT) refers to, depending on the context, approach, concept, formula, method, model, pattern, project, theme, etc. In Mandarin Chinese, it is JianZhao, YingYung, and YiJiao, respectively. For advantages and disadvantages, see Wild, et al, (2008: 378). However, the concept has been in operation for centuries. BOT is a project financing and operating approach that has found an application primarily in the area of infrastructure privatization (Brown and Schmidt, 1999). For many countries, financial markets are shifting the way "debt capital is raised to fund the development of infrastructure. In the past, debt was raised directly from multilateral and export credit agencies or from sovereign governments themselves to provide turnkey financing. Recently, infrastructure developers have turned increasingly to portfolio-style credit in the form of capital pools, operating concessions and stand-alone utilities. This has changed the traditional contractor's role from being a service provider to being a business partner in the operation of the enterprise" (Brown and Schmidt, 1999). How does it work in the United States?

Most of the early turnpikes and canals in America are "operated on the principle that a grantor, usually but not always a government body, would offer an operating license to a concessionaire for a long term contract to develop and operate a transportation company with exclusive rights to a length of road or river. Over time, the concept was extended to include frontier postal services, local telephone services, electrical utilities and many municipal service functions such as land management. In this way, infrastructure upgrades were financed without public funding, and a method of long-term payback from operating revenues was established with a contract period deemed lengthy enough to make the operating concession a lucrative project" (Brown and Schmidt, 1999).

The experts continued by saying that "[in] the modern setting, a cash-strapped corporation, municipality, county or state will enter into a profit sharing agreement with a concessionaire. This profit sharing principle is the key aspect differentiating the BOT approach from the outsourcing arrangements commonly undertaken in the country. The concessionaire will operate as an independent business organization contractually accountable for a series of technical, operational and service related goals. The contract will often be setup such that the risk of 
revenue fluctuation is offset to the concessionaire by means of a fixed fee obligation to the owner. The upside to this arrangement, however, can be considerable if revenues are better than anticipated..." (Brown and Schmidt, 1999).

A number of variations on the BOT theme have emerged from the experience of international infrastructure development, which differed mainly in the exact ownership and payment arrangement between the owner and the concessionaire on completion of the construction portion of the contract. The main approaches are summarized in Table 1 (Brown and Schmidt, 1999).

Due to rapid, changing trends, concepts like Build, Own, Operate, and Transfer (BOOT), Design, Build, Operate, and Transfer (DBOT), as well as Public-Private-Partnerships (PPP) have also been arisen in the outsourcing market. Needless to say, if things did not go smoothly, Build, Operate, Litigation (BOL) could surface (ZHAO and WANG, 2010). One example is the Taiwan High Speed Rail Corporation (THSRC)'s three-dimensional trademark which failed to be accepted by the Taiwan area's Intellectual Property Office (TIPO) under the Ministry of Economic Affairs (MOEA), and, later, the Taipei High Administrative Court (THAC) in September 2007 endorsed TIPO's decision, because 700T lacks distinctiveness for registration purposes (Cong S.Y., 2009).

Many of the Taiwan area government officials are educated in the United States, such as MAO Chi-kuo, the incumbent Minister of Ministry of Transportation and Communications (MOTC) since May 2008 and the then second Director of the Preparatory/Preparation Office of the Bureau of High Speed Rail (BHSR) from September 1991 to March 1993 (Ministry of Transportation and Communications, 2010). Because of their past knowledge, training, and connections, one can assume that they would either encourage or propose to the government the novel, foreign BOT experience. To the people in the Taiwan area, it would mean that the private sector acquires permission to invest and set up the project. After a period of operation, the asset will be transferred to the government (Bureau of High Speed Rail, MOTC, 2010).

\subsection{Background of the High Speed Rail BOT in the Taiwan Area}

The case study that we are discussing has to do with Taiwan Province's BOT. The Chinese mainland (NeiDi) is different, and it has a total of 6,552-kilometer high speed rail done for commercial operation, new lines, and upgraded old lines, ranking number one in the world, as of March 2010. An overall picture should be first given. It should be noted that Taiwan Island itself is well known for its rugged central mountainous terrain, which has restrained its migration and constrained the socio-economic growth mostly along the plains of the West coast areas or Western corridors, which has $94 \%$ of the island population. The construction crosses 14 counties, 68 townships, and 32 urban planning districts. For years, in an effort to balance the development of northern Taiwan and southern Taiwan, which is about the same distance as New York City and Washington, D.C., demand for North-South intercity transportation and regional daily commuting and business trips began to be vocal. In response, the Taiwan High Speed Rail Corporation (THSRC) mapped out a strategy to form the THSR as the longitude, and the district mass transit as the latitude, thereby becoming a public transit web, and smaller trains and local buses will link the new stations to downtown (Bradsher, 2007).

However, the construction engineers had to overcome many problems at several locations, for example, the Yunlin County section, where the elevated railway crosses Provincial Expressway No.78 in the county that has subsided by 55 centimeters over the past seven years. As another example, at the southern section, the THSRC had to build 157-kilometer continuous viaduct, which is the longest elevated structure in the world. Even before the operation, a series of commercial disputes "...has produced a remarkable hodgepodge: French and German train drivers who are allowed to speak only English with Taiwanese traffic controllers while operating Japanese bullet trains on tracks originally designed by British and French engineers" (Bradsher, 2007).

Informal planning began as early as the 1970s. The first formal plan by the Ministry of Transportation and Communications Preparatory Office of the BHSR for a 345-kilometer (207-mile) High Speed Rail (HSR) line, which has 48-kilometer tunnels along the way, linking the metropolises of Taipei and Kaohsiung, began in July 1990. They were then approved by the Executive Yuan (equivalent to the cabinet) in June 1992 and the Legislative Yuan (branch) in July 1993. However, the latter scrapped the national budget for building the HSR line and stipulated the BOT method. In December 1994, the Encouragement/promotion of Private Participation in Transportation Infrastructure Projects Statute, stating the required rules and policies for the project including a clause saying the government can take over a BOT project, was passed by the Legislative Yuan. A tender invitation for Private Participation in Construction and Operation of Taiwan North-South High Speed Rail Project was thus made by the government in October 1996.

Later, in a prolonged bidding process, the Taiwan High Speed Rail Consortium (THSRC) ran against the Chunghwa/Chinese High Speed Rail Consortium (CHSRC). The THSRC's bid was based on the hyper-modern 
technology platform of Eurotrain, a joint venture of General Electric Company (GEC)-Alsthom and Siemens AG, while CHSRC's bid was based on the Shinkansen new main line (also known as the bullet train since October 1964) technology of Japan. THSRC also promised to build the line entirely from private capital. In September 1996, the THSRC was selected the best applicant. The group as the concessionaire was renamed and formally incorporated with the same acronym, THSRC, in May 1998. Two months later, the literally BOT agreements were signed between the MOTC and the THSRC, which granted the latter a concession to finance, construct, and operate the HSR System for a period of 35 years and a concession for ultra-modern, attractive HSR station area development for a period of 50 years. In September 1999, there was a big earthquake in the Taiwan Island, which prompted the issuance of contracts of the civil infrastructure works, due to the concern of the design and construction methods. In March 2000, the first contract of the civil works was awarded and the construction of the HSR began. The Roll-out Ceremony for the sleek bulbous-nosed THSR 700T trains took place in January 2004 at Kobe, Japan, marking the first time that the Shinkasen exported its system to a foreign country. In January 2007, the futuristic train, run at maximum speeds of 300 kilometers (186 miles) per hour, began to welcome the first paying passengers for test rides. In the following month, normal operations officially began.

As it turned out, by February 2009, what was meant to be a source of pride, for example, holding the world record for having longest viaduct at 157.3 kilometers from Baguashan, a mountain park, in Zhanghua County to Zuoying District in Kaohsiung Municipal City, had turned into a rich source of embarrassment, incurring enormous debts, which amounted to NT\$70.2 billion (US\$2.1 billion) in losses or roughly two thirds of its capitalization. The corporation is supposed to start paying back the loan from 2009 to 2022 . Yet, it is only able to pay back the interests. Because the THSRC was unsuccessful, it is necessary for us to find out who should likely be accountable for the whole mess (Borneo Post (BP), 2009; ShiHuan Daily News (SHDN), 2009 (September 25 and 28)).

\section{Who Should be Accountable?}

There are several key players throughout the development. The first key player is the Taiwan area government. The second one is the original five shareholders of the THSRC, namely, Continental Engineering Corporation (CEC), Pacific Electric Wire and Cable Company (PEWC), Evergreen International Corporation (Evergreen), TECO Electric and Machinery Company (TECO Group), and Taipei Fubon Commercial Bank Company (TaipeiFubon). The third one can be regarded as the contractors, who can, in turn, inter alia, convince or endorse the multilateral and export credit agencies, bank creditor, or from sovereign governments themselves to provide turnkey financing. Last but not least, passengers and consumers (or consumer advocates) or even experts on BOT and tax-payers can be regarded as another key player.

\subsection{The First Player's Fault: Government}

It is not difficult to find fault with the government. First, some talk show guests in the Taiwan area accused the second player for setting up the PianJu (hoax/fraud/swindle). If so, did any central, provincial, and local officials or elected officials get personal gains or benefits or were they concerned with the integrity of HSR projections, including (commuter) ridership, costs, revenues, and associated public benefits? We can pose this question by simply citing the following three sentences: "California seems certain to leverage private funds for its $\$ 40$ billion-plus high-speed rail project. But just how much can it demand from for-profit sources? And who will benefit?" (TransportPolitic, 2010). Another analogy has to do with the Union of Myanmar (UOM). In a March 2010 report, readers were told that even the military junta in the UOM, which imposed martial law and which seized state power in August 1988, has taken in the past six months steps to privatize the nation, trying to sell off about 250 petrol stations, four ports, and state-owned buildings including warehouses and cinemas. However, the following tough questions were raised: Does the military regime want to reform the economy or to take profits before the 2010 multi-party general elections, which was scheduled in November? (BP, March 15, 2010). Perhaps one can make similar assertions about the government officials and politicians in the Taiwan area.

Second, early on, it was not clear how much it would cost to be able to operate the system and how serious construction cost overruns would be. The THSRC's website mentioned US\$18 billion, making the project undoubtedly the largest privately managed and funded BOT project in the world at the time on initiation and perhaps even by June 2006 (Skyscrapercity, 2010). Other sources, such as the January 4, 2007 report by the Associated Press (AP), mentioned US\$15 billion. Other figures include US\$12.5 billion, US\$16 billion, and NT $\$ 420$ billion. The exchange rate is roughly US $\$ 1=$ NT\$33. The amount of money certainly included compensation for requisition of private land and resettlement for residents of demolished houses.

Third, in April 2009, if not earlier, the then THSRC chairwoman, Nita C. ING, began to sense that she might have to step down (TVBS, 2009). In September 2009, analysts were asking how would the government initiate a 
takeover. Would it attempt to control the majority of the board of directors, given the fact that even the government is in financial difficulties plus the fact that, in the words of anonymous MOTC officials, it is incapable of running the THSRC as a state-run business at the moment (TaiwanToday, 2009). For example, the executives of a government-run company could not possibly have annual salaries in the NT\$10 million (US\$330,000), as more than 20 incumbent THSRC executives, out of more than 3,000 employees, received (SHDN, September 25, 2009). In other words, when talented individuals resign from the corporation due to a reduction in their salary, would this invite safety problems?

A related question must be posed: Was the government proactive? The answer is no. For example, in September 2009, chairperson of the Board of Directors of the Bank of Taiwan (BT), Susan S. Chang, said by October of the same year the debt-ridden THSRC can secure new funding as part of efforts to pay off earlier loans (SHDN, September 25, 2009). Yet, it was not until January 2010 that a NT\$382 billion (US\$12 billion) syndicated loan at an interest rate below $1.8 \%$ was signed to enable the THSRC to pay off existing loans, which were obtained at higher interest levels during the project's construction, thereby enabling the same corporation to save NT $\$ 2$ billion per year (Manila Bulletin, November 21, 2009).

Fourth, several government or semi-official agencies and joint ventures were forced to contribute money to the THSRC, especially under the CHEN Shui-bian regime. For example, Aerospace Industrial Development Corporation (AIDC) had to invest by buying preferred shares, as opposed to common shares, amounting to NT\$4.5 billion. As another example, Taiwan Financial Holdings Group (TFHG), the parent of Bank of Taiwan, also bought preferred shares. Would that make the THSRC complacent, thinking that no matter what the government will have to make sure that the corporation is solvent (Wapedia, 2010).

Fifth, domestic politics was certainly involved. ING said: "I can't tell you how many people we offended from the south to the north. Out of concern for my security, one director told me, 'You have too many enemies. You will always be a target here.' From the time the project began, we have never given anything to any elected official," adding her own company since her father's days has never gotten involved with the government and the ING family had always steered clear of politics (WU and CHEN, 2009).

It goes without saying that international politics was also involved. In October 1997, the Eurotrain consortium was declared the preferred bidder to supply trains and equipment and execute the actual construction. However, in December 1999, the THSRC instead chose the Japanese bidder, signing a memorandum of understanding (MOU). As can be seen, Siemens and Alstom protested. However, their protest was also rejected by the High Court in the Taiwan area. Nevertheless, the THSRC in November 2004 agreed to pay US\$65 million in compensation to the Eurotrain consortium, which in February 2001 filed a damage claim to the Singapore International Arbitration Centre (SIAC) (Wapedia, 2010). The reason is simple and straight forward, the Taiwan area needs help from Japan more than it needs assistance from European countries, so as to deter mainland China's military threat or attack.

Sixth, did the government have a strategy to try to help the four domestic airline companies and other transportation companies, such as conventional train and long-distance bus, which obviously have to scale back their service, thereby inevitably becoming the main casualty? To be sure, at least one old airline company closed its doors in May 2008, after a chain of financial crises (China Times, 2010a).

\subsection{The Second Player's Fault: Original Shareholders}

Again, a number of faults by the original shareholders can be easily cited. First, there was uncertainty all along in the minds of the original shareholders, who only took a chance to play the game. It is fair to say that, on the one hand, they were gambling and they feel that they have nothing to lose. On the other hand, they can always award the sub-contracts for core systems, trains, electrification, signalling, and other electric and mechanical systems to local companies that they have been associated with. There were also loopholes in the contract. Thus, in September 2009, ING reportedly asked for a compensation of NT\$5 billion for her loss from the government. If she gets the compensation, would she be richer than before, when she was in charge of the BOT?

Second, the second player had a bit of confidence but they are not fully sure whether they can operate the rail for 35 years. They can only tout for the best case scenario--being able to make at least a modest profit. In November 2006, the THSRC said it expected to be profitable by its second year and to break even 12 months after its first commercial operation, adding "[ $\mathrm{t}] \mathrm{he}$ plan is to manage returns from the investments after 16 years from construction" (AFX News Limited, 2006). So, their logic was simple and straightforward: Live day by day and make as much profit as possible, and, in the worst case scenario, they just have to choose not to serve in the board of directors, so long as they are clean. Besides, they can assure the government and the public that they will only commission the best experts, for example, Mott MacDonald and Moh \& Associates, which can provide 
a comprehensive asset management strategy for the project's civil infrastructure, such as engineering for the inspection and maintenance, procedures and people competencies, as well as guidance on the inspection process itself (MacDonald, nd).

Third, they would usually only say good things about the THSR system, such as relief of traffic congestion, saving energy, and preserving the environment, as if the win-win scenario can materialize. Did the original shareholders of the THSRC mention to the public that the short Paris-Lyon and Tokyo-Osaka routes are the only ones in the world that have broken even (Newsgeography, nd). It goes without saying that the original shareholders would not challenge the planners' (erratic) prediction of the projected passengers--280,000 each day, as opposed to a mere 87,000 in September 2009. In January 2010, we see an increase in the daily number of passengers, averaging 93,000, which represents an average seat use rate of about $46 \%$. What about the corporation, which in May 2008, aimed for a maximum of 145,000 trips per day by 2033. However, it should be noted that ING herself admitted in September 2009 that the government, indeed, inflated the estimates to make the railway more attractive to investors (WU and Chen, 2009).

Fourth, estimates by the government's Council of Economic Planning and Development (CEPD) also painted a rosy picture, that is, the construction of the HSR network can create 480,000 jobs and may contribute $1 \%$ point to economic growth (AFX News Limited, 2006), including property developments surrounding the bullet train stations and depots.

The operations of the THSR system had been re-scheduled a few times. A government newspaper mentioned October 2005 as the original launching date. However, a delay in the completion of the project's core electrical systems forced a further delay to October 2006. On November 30, 2006, Lloyd's Register issues a safety certification. The corporation also cancelled a December 7, 2006 opening ceremony, after the government said further tests were necessary before the HSR system could be in commercial operation. Finally, on January 5, 2007, the high-speed train was opened to paying passengers.

\subsection{The Third Player's Fault: Contractors}

From the available source materials, the third player, the contractors, have been involved in the least. So long as the original shareholders of THSRC can initiate the move to find experienced, trusted, and internationally well-known consortiums, such as Japan's Mitsubishi Heavy Industries (MHI), Ltd. and Sumitomo Mitsui Banking Corporation (SMBC), bankers, both at home and abroad, can be easily persuaded, even though, on top of their head, they know that capital-intensive, credit environment of international infrastructure development is highly risky (Flyvbjerg, Bruzelius, and Rothengatter, 2003; Cox, 2006). To be sure, some of the consortiums may even promise to provide soft loans with very low interest rates, only to charge higher service fees later on, so as to make up for the loss.

\subsection{The Fourth Player's Fault: Consumers}

The THSRC lost a lot of money, after less than two years' operations. In the context of the Taiwan area's foreign exchange reserve, it may not mean much because of Taiwan's large foreign exchange reserves. As of October 2010, mainland China has the most foreign exchange reserves, to be followed by Japan, Federation of Russia (FR), the Taiwan area, Republic of India (ROI), and Republic of Korea (ROK). What it means is that the tax-payer has to foot the bill. Before awarding the project to the THSRC, the Legislative Yuan withdrew the budget allocated to the HSR, as mentioned earlier. It seems to be a relief to the tax-payers at that time. However, it turned out that, after the mass media began to publicize the near-bankruptcy of the THSRC, the government had to absorb more loss, tangible and intangible. According to one report, the total cost of the HSR project grew, and critics pointed out that the cost meant about US\$650 for every man, woman, and child in the Taiwan area (Wapedia, 2010). And according to the June 9, 2009 issue of ShangYeZhouKan (Taipei), it is NT $\$ 17,000$ per person in the Taiwan area, and the government could have used the money to build six Taipei 101 Towers in Taipei City. When Taipei 101 Tower opened to the public for the first time in December 2004, it was the world's tallest building. What are some of the faults?

First, we learned from a news report that the Taipei-based Taiwan Institute of Economic Research (TIER) does have experts on BOT (BP, September 28, 2009). What did the experts on BOT have to say? Did their opinion make a strong impact on the government and so on and so forth?

Some research outputs can be easily accessed. In early 21 st century, knowing that the double-track railway line runs through an extremely active seismic area, CHANG, et. al. wrote about the sealing work under difficult conditions in seismically affected ground, such as the Linkou tunnel (CHANG, Lemke, and Noda, 2010). Another research paper or scenario analysis introduced the financial model used by the BHSR for its BOT 
projects, presenting the parameters, such as debt/equity ratio, and variables, such as annual operating income and affiliated business income in the operating period, of the model, taking account of the investment proportions of the government and the concessionaire, the concession period, and other items featured in BOT projects, as well as discussing the model's basic assumptions, input data, cost requirement, self-financing ability analysis, financial statements, and indices (CHANG and CHEN, May/June 2001). An ex post cost-benefit analysis of the HSR system including several policy suggestions was also conducted (Cheng, 2010). Studies have also been made in full detail with special discussion on major issues encountered during the design works for one of the special bridges. In addition, seismic design had been considered particularly critical for HSR structures, and it was based on an earthquake with a return period of 950 years (Kang, Peng, and Chua). For the record, the THSRC organized the High Speed Rail in Asia Symposium and the Recognition and Appreciation Ceremony in October 2007 in Taipei, sharing its experience with transport officials at home and abroad; system providers, suppliers, and operators; contractors; consultants; and investment bankers, as if private funding to the transport projects can be replicated elsewhere in the world, with success. The related problem is that many legislators, bankers, etc. are not experts on BOT, engineering, and other related matters. So, how can they pin point the real problems?

Second, riders or commuters are actually powerless, because of lack of information from the experts and agencies responsible for reporting to the public. Therefore, commuters can only complain, if something went wrong. The THSR system encountered some operational problems, such as lingering safety concerns and embarrassing, widespread technical ticket glitches, plus the fact that some ticket buyers could not swipe their credit cards. In March 2010, a Richter scale 6.4 earthquake jolted Taiwan, and one of the THSRC's lead cars was derailed. In April 2010, a driver, while operating the bullet train, was found to be overdosed with sleeping pills (China Times, 2010b). The THSRC people in charge can only apologize to the passengers and/or make refunds.

Third, needless to say, some consumers, who choose not to heed what the chairman of the Consumers' Foundation Chinese Taipei (CFCT) had said--cherish your life, don't be a guinea pig, until extensive safety data has been released are happy that, as a result of having the HSR system, the people of Taiwan Island can live in an "one-day peripheral circle" or "one-day community," meaning that a housewife can take the train in the morning from Kaohsiung to Taipei, so as to eat a delicious bowl of beef noodle with epicurean delight or visit a close friend as well as come back before dinner time, without rush. If one were to take a slower train, it would usually mean four or five hours one way. And, if one drives a car, normally, one has to be on the wheel for six hours or more, if there was a car accident on the superhighway (Bradsher, 2007).

\section{Conclusion and Recommendations}

Lessons should be learned from this case study, because another BOT project, the Kaohsiung Metro, which capitalized at NT\$10 billion and which opened service in March 2008, is also in trouble since September 2009, already losing $60 \%$ of its paid-in capital or NT\$6 billion, when CHUANG Chi-wang, speaker of the Kaohsiung City Council (KCC), said that the Kaohsiung Mayor must get ready to take over the ailing Kaohsiung Rapid Transit Corporation (KRTC) by the end of 2009. Because in late November 2010 the 2010 municipal elections in the Taiwan area will be held for the first time in newly created special municipalities including Kaohsiung, we do not hear much negative news regarding the KRTC. First, there is no guarantee that all BOT projects can be successful. ING in September 2009 began to in public blame the government, for being untrustworthy and consistent (WU and CHEN, 2009). Yet, there are always some entrepreneurs coupled with government officials and politicians who want to take risks, if the government has made promises again.

In April 2009, the Barack H. Obama, II administration initially released an outline for a national 10 high-speed rail corridors across the United States. In January 2010, Obama at the State of Union speech announced the program, and, a day later, he said the federal government will spend $\$ 8$ billion developing the nationwide high-speed train system, probably using Japan's latest N-700-I system, a variant of the 700 Series Shinkansen and an investment which is much needed to help spur long-term economic growth and which will be funded through the government's US $\$ 862$ billion economic stimulus package. In a hotly controversial statement California reported that it may buy high speed rail system from mainland China (CNN, January 29, 2010). In the same month, a HSR Seminar, Kawasaki's High Speed Train Technology and Contributions to the US Society, was held in Washington, D.C. In May 2010, The American Transportation Secretary took a test ride on Japan's super-fast magnetic train. However, would the United States repeat the THSRC's near-bankruptcy blunder? The following citation should be remembered: The recent failure of Taiwan High-Speed Rail raises questions about the role of private investment in new trains systems. The California High-Speed Rail Authority projects that it will need about 33 billion in 2008 dollars to complete its initial San Francisco-Anaheim link, a reasonable estimate considering the cost of peer systems. In addition to the 9 billion in state funds devoted to the project by 
last November's referendum, the Authority is banking on \$2-3 billion in local money and \$12-16 billion in federal contributions, " adding "because this aid won't be enough to cover the full costs of the line" (TransportPolitic, 2010).

If not, would the American aviation industry be hurt, because, once in full operation, lesser people would take the airplanes or even drive their car. In this connection, America can cut use of oil by 125 million barrels a year, says Rob McCulloch, transportation advocate for Environment America, a citizen-based environmental advocacy group (Clayton, January 28, 2010).

Another lesson is that, in all phases, everything must be transparent. A sanctions regime must be formed, so as to monitor as much as possible the whole development. This applies to the period after the transfer of operation from the government to the private owners, so that officials will not be erroneously regarded as corrupt and business people, villains.

Some findings can be noted. First, it is a human tendency to blame others first. Whether the high speed rail is in the hands of the government or privately run, some day, somehow, the system will malfunction. So, blame can be easily lodged. If blaming is the name of the game, should we blame harshly on each key player in this case study? It is not necessary. Business failure is very common. According to observation, nine out of ten businesses fail. Besides, the passengers and consumers should be blamed the least, because they are like a heap of sand, unable to stick together like clay.

Second, ING said she indirectly felt deceived by the Government "we were too naïve" (WU and CHEN, 2009). In human affairs, we often see conspiracy theories, hoax, etc. Many audiences have also watched the movie, The Sting. The authors believe that none of them can be applied 100\% to the THSRC case. There are simply too many things beyond the ability of an individual or a small group to conspire, command, and ultimately control the whole operation.

Third, why did not the THSRC declare bankruptcy? Trying to preserve the government's face may have played an important role. The premier may have to step down, to take the final responsibility. Thus, the government could not allow the corporation to declare a worst-case scenario-default on loans, and there is consensus on the matter between MAO and ING. The former said, after becoming the minister in May 2008, he had talked to ING in person about five or six times $(S H D N, 2010)$.

Fourth, not all government officials were corrupt, because ING mentioned that "our original shareholders invested in the project based on a package of incentives that lured them on board. Later, the government said it was unable to help, because such assistance would constitute graft" (WU and CHEN, 2009). Sometimes, the original shareholders were wrongly blamed, because it is difficult to engage in land speculation and because the government is by far the biggest landowner (WU and CHEN, 2009).

Last but not least, there is one potential issue, which remains to be seen, that is, would mainland China with a huge foreign exchange reserve, ranking number one in the world, takeover the HSR system one day, as one ruling party legislator guessed, in which the financial obligations will be its responsibility? This possibility can never be ruled out.

\section{References}

AFX News Limited. (2006). Taiwan high speed rail sees operating profit in second year of operation. [Online] Available: http://www.forbbbes.com/feeds/afx/2006/11/30/afx3215855.html. (7 May, 2010)

Borneo Post (BP). (2009, September 28). Taiwan high speed rail. (Sarawak, Malaysia), B3.

BP. (2010, March 15). Towards high speed rail improvement. B2.

Bradsher, K. (2007). Taiwan's bullet trains can't outrun controversy. New York Times. Retrieved $7^{\text {th }}$. [Online] Available: http://www.nytimes.com/2007/01/04/world/asia/04taipei.html. (May 2010)

Brown, R. W., and Schmidt, P. (1999). BOT (Build, Operate and Transfer) an alternative to traditional data conversion and management, GISdevelopment.net ---> GITA 1999. [Online] Available: http://www.gisdevelopment.net/proceedings/gita/1999/business/ba003pf.htm (May 8, 2010)

Bureau of High Speed Rail, MOTC. (2010). [Online] Available: http://www.hsr.gov.tw/homepage. nsf/beff9cd 4905e 8649482569210010e4a3/76ee4cc04fed6f13482570a100149a79! OpenDocument. (May 10, 2010)

CHANG, M., Lemke, S., and Noda, J. (2010). Taiwan high speed railway project C210. [Online] Available: http://www.gquadrat.de/media/get_foto.php?id=33. (May 7, 2010)

CHANG, L., and CHEN, P. (May/June 2001). BOT financial model: Taiwan high speed rail case. Journal of 
Construction Engineering and Management, 127(3), 214-222.

CHENG, Y. (2010). High-speed rail in Taiwan: New experience and issues of future development. Transport Policy, 17(2), 51-63. [Online] Available: http://www.sciencedirect.com/science/article/B6VGG-4XM6N9T 1/2/f006e0c3311300f3ee 5ea15a 806 baf.

China Times. (2010a). Taiwan high speed rail. [Online] Available: http://life.chinatimes.com /2009Cti/Channel /Life/lifearticle/0,5047,11051801+112009111300042,00,focus.html. (7 May, 2010)

China Times. (2010b). Driving drowsy high speed rail: High Speed Rail Bureau jointly hidden. [Online] Available: http://news.chinatimes.com/focus/0,5243,50105318x112010051100133,00.html. (11 May, 2010)

Clayton, M. (January 28, 2010). Obama's high-speed rail plan: Which states get the money? [Online] Available: http:/www.csmonitor.com/USA/Politics/2010/0128/Obama-s-high-speed-rail-plan-Which-states-get-the-money. (11 May, 2010)

CNN. (29 January, 2010). Obama announces $\$ 8$ billion investment in high-speed train system. [Online] Available: http://edition.cnn.com/2010/POLITICS/01/28/obama.trains/index.html. (11 May, 2010)

Cong S.Y. (2009, $5^{\text {th }}$ September). Financial roaming- too hard to change the financial market knowledge. China Times. [Online] Available: http://news.chinatimes.com/2007Cti/2007Cti-News/2007Cti -News-Content/0 $4521,11051401+112009092600384,00$,html. (May 7, 2010)

Cox, Wendell. (2006). War on the dream: How anti-sprawl policy threatens the quality of life. Bloomington, IN.: iUniverse, Inc..

Flyvbjerg, B., Bruzelius, N., and Rothengatter, W. (2003). Megaprojects and risks: An anatomy of ambition. Cambridge: Cambridge University Press.

Hassan, M. H., and Mohamed, R. S. (May 7, 2010). 911 conspiracy theories: The absent perspectives. RSIS Commentaries, 46. (10 May, 2010)

Kang, SM., Peng, HK., and Chua, HY. (nd). Design of A Special Bridge for Taiwan High Speed Rail Project Lot C296. MAA Group Consulting Engineers: Taiwan. [Online] Available: http://www.maa. com.tw/common /publications/2000/2000-067.pdf. (22 May 2010)

MacDonald, M. (nd). Taiwan High-Speed Rail. [Online] Available: http://www.railways. mottmac.com/projects $/$ ?mode=type\&id=121502. $(7$ May 2010)

Manila Bulletin. (21 November 2009). Taiwan high speed train company to refinance debt. [Online] Available: http://www.mb.com.ph/articles/230499/taiwan-high-speed-train-company-refinance-debt. p.B4. (7 May, 2010)

Ministry of Transportation and Communications. (2010). Retrieved May 20 2010 . [Online] Available: http:/www.motc.gov.tw/mocwebGIP/wSite/ct?xItem=4266\&ctNode=203\&mp=2.

Newsgeography. (nd). High speed rail toward least worst projections. [Online] Available: http://www.newsgeography.com/content/001344-high-speed-rail-toward-least-worst-projections.( May 7, 2010)

SHDN. News bulletin. (September 25, 2009), p.11.

SHDN. News Bulletin. (September 23, 2010), p.11.

ShiHua Daily News (SHDN). News bulletin. (September 26, 2009). (Sarawak, Malaysia), p. 8.

Skyscrapercity. (2010). Taiwan high speed Shinkasen train. [Online] Available: http://www.Skyscrapercity com/showthread.php?t=367080. (7 May, 2010)

Taiwwan Today. (28 September, 2009). Analysts foresee government high-speed rail takeover. [Online] Available: http://taiwantoday.tw/fp.asp?xitem=65921\&CtNode=452. (7 May 2010)

Transport Politic. (2010, April 2nd). Archive for the 'California High-Speed Rail' category finding an appropriate role for PPPs in the infrastructure-creation process. [Online] Available: http://www.thetrans portpoli tic .com/category/places/california-high-speed-rail/. (May $2^{\text {nd }} 2010$ )

TVBS. (2009). 2100 program (Taiwan, R.O.C.). September 21, at 9 pm.

Wapedia. (2010). Taiwan high speed rail. [Online] Available: http://wapedia.mobi /en/Taiwan_High_Speed _Rail.( 7 May, 2010)

Wild, J. J., \& Wild, K. L. (2008). International Business, (4 ${ }^{\text {th }}$ ed). Upper Saddle River, N.J.: Pearson and Prentice Hall, 378-382. 
WU, Yin-chuen and Yi-Shan CHEN. (2009). Nita ING bows out. Commonwealth Magazine, 431 (September 24).

ZHAO, GuoFu and ShouQing WANG. (2010). Indicators of social impact assessment for BOT/PPP projects. [Online]Available:http://management.kochi-tech.ac.jp/PDF/SOCIAL_MANAGEMENT_ INFRA /SESSION _B4/smsri_29_Zhao.pdf. (May 17, 2010)

Table 1. Different Forms of Infrastructure Financing and Operation

\begin{tabular}{|c|c|c|c|}
\hline Build-Transfer-Operate & Build-Own-Operate & Build-Transfer-Operate & Build-Lease-Transfer \\
\hline $\begin{array}{l}\text { The contract will specify } \\
\text { the upgrade and operation } \\
\text { of the enterprise by the } \\
\text { concessionaire for a fixed } \\
\text { period of time followed } \\
\text { by the transfer of all } \\
\text { facilities and equipment } \\
\text { back to the owner. }\end{array}$ & $\begin{array}{l}\text { The concessionaire is } \\
\text { essentially buying the } \\
\text { basic facility in } \\
\text { instalments from the } \\
\text { owner, with the facility } \\
\text { and it's upgrades provided } \\
\text { as security over the } \\
\text { repayment period. On } \\
\text { completion of the } \\
\text { contract, ownership } \\
\text { reverts to the } \\
\text { concessionaire. }\end{array}$ & $\begin{array}{l}\text { The concessionaire builds } \\
\text { and transfers a facility to } \\
\text { the owner but exclusively } \\
\text { operates the facility on } \\
\text { behalf of the owner by } \\
\text { means of a management } \\
\text { contract. }\end{array}$ & $\begin{array}{l}\text { The concessionaire builds } \\
\text { a facility, leases out the } \\
\text { operating portion of the } \\
\text { contract, and on } \\
\text { completion of the } \\
\text { contract, returns the } \\
\text { facility to the owner. }\end{array}$ \\
\hline
\end{tabular}

